\title{
Towards a Thousand Little Morias: The EU (Non-)Rescue Scheme - Criminalising Solidarity, Structuralising Defection
}

Violeta Moreno-Lax"

\section{Introduction: Saving Lives by Pre-empting Arrivals ${ }^{1}$}

The ambition of the New Pact on Migration and Asylum is to 'build a system that manages and normalises migration for the long term and which is fully grounded in European values and international law', ${ }^{2}$ avoiding the kind of piecemeal ad hoc-ism that may degenerate in Moria-like fiascos. ${ }^{3}$ This requires a 'comprehensive approach' that recognises 'collective responsibilities ... and tackles the implementation gap' of the relevant standards, ${ }^{4}$ while ensuring solidarity, including in the maritime domain. ${ }^{5}$ Search and rescue (SAR) is acknowledged by the European Commission not only as 'a moral duty and a ... [binding legal] obligation under international law', but also as 'a key element of the European integrated

* Professor, School of Law, Queen Mary University of London and Visiting Professor, College of Europe (Bruges).

1 This chapter draws from Moreno-Lax, 'A New Common European Approach to Search and Rescue? Entrenching Proactive Containment' (EU Migration Law Blog, 3 February 2021) <https://eumigrationlawblog.eu/a-new-common-european-appro ach-to-search-and-rescue-entrenching-proactive-containment/>; and from Violeta Moreno-Lax and others, 'The EU Approach on Migration in the Mediterranean', PE 694.413 (European Parliament 2021), 70-117 <www.europarl.europa.eu/RegDa ta/etudes/STUD/2021/694413/IPOL_STU(2021)694413_EN.pdf>. All websites last accessed 17 November 2021.

2 'New Pact on Migration and Asylum', $\operatorname{COM(2020)609~final,~} 23$ September 2020, 1.

3 Ibid, 3 and 13. See also 'Moria Migrants: Fire Destroys Greek Camp Leaving 13,000 without Shelter' (BBC, 9 September 2020) <www.bbc.com/news/world-europe-540 $82201>$.

4 'New Pact on Migration and Asylum' (n 2), 3. For an alternative understanding of the 'comprehensive approach' required, see Violeta Moreno-Lax and Efthymios Papastavridis (eds), 'Boat Refugees' and Migrants at Sea: A Comprehensive Approach (Brill 2016).

5 'New Pact on Migration and Asylum' (n 2), 5-6. 
border management' and 'a shared responsibility' of both the Union and its Member States. ${ }^{6}$

However, the focus-as with much of the New Pact-is neither on the protection of seaborne migrants and refugees nor on the elimination of the structural factors that push them to take the sea to reach safety in the first place. The main concern is with managing mixed flows and countering irregular arrivals on consideration that '[d]angerous attempts to cross the Mediterranean continue to bring great risk and fuelling criminal networks'. ${ }^{7}$ Accordingly, the measures proposed to develop a 'common European approach to search and rescue' centre on 'ensuring effective migration management', ${ }^{8}$ rather than enhancing the SAR response, providing safe passage opportunities, or establishing legal pathways to protection.

Five elements are expected to achieve this objective: (1) a more predictable relocation mechanism for disembarkations; (2) enhanced cooperation and coordination among Member States; (3) the deeper involvement of Frontex through increased operational and technical support; (4) the fight against the facilitation of irregular entry; and (5) strengthened cooperation with countries of origin and transit to prevent unauthorised crossings. ${ }^{9}$ These measures may, as an add-on, 'contribute to saving lives at sea', ${ }^{10}$ but this is not the priority. The priority is to curb 'dangerous journeys and irregular crossings' in partnership with third countries and the prevention of the facilitation of unauthorised arrivals. ${ }^{11}$

This entrenches a two-pronged model of proactive containment, ${ }^{12}$ which prioritises the fight against irregular migration above all else. ${ }^{13}$ On the one hand, it relies on countries of origin and transit as deputised (extraterritorial) enforcers of Schengen controls and, on the other hand, it targets irregular movement through the criminalisation of smugglers, traffickers, and anybody who facilitates unauthorised arrivals, ${ }^{14}$ except in

6 Ibid, 13.

7 Ibid.

8 Ibid, heading of section 4.3 and p. 14.

9 Ibid, 13-14.

10 Ibid, 13 (emphasis added).

11 Ibid, 14 and sections 5 and 6.

12 Violeta Moreno-Lax and Mariagiulia Giuffré, 'The Rise of Consensual Containment: From "Contactless Control" to "Contactless Responsibility" for Migratory Flows' in Satvinder Singh Juss (ed), Research Handbook on International Refugee Law (Edward Elgar 2019) $81<$ www.unhcr.org/5a056ca07.pdf .

13 See chapters by Elspeth Guild and Paula García Andrade in this collection.

14 See, e.g., FRA, 'June 2020 update - NGO ships involved in search and rescue in the Mediterranean and legal proceedings against them' (19 June 2020) <https://fra 
limited circumstances discussed below. In my view, what the common European approach to search and rescue thereby amounts to is the official endorsement and formal entrenchment of the rescue-through-interdiction/rescuewithout-protection paradigm that has developed in practice over the past years, ${ }^{15}$ since Frontex launched its first maritime (border surveillance) operation back in $2006 .^{16}$

In its latest stages of formation, this model has been characterised by an 'interdiction by omission' strategy, ${ }^{17}$ based on the negation of rescue, ${ }^{18}$ including through outright abandonment of survivors at sea, ${ }^{19}$ the withdrawal of naval assets from Frontex and EUNAVFORMED operations, ${ }^{20}$ or the reduction of operational areas covered by maritime missions to avoid contact with potential 'boat migrants', ${ }^{21}$ as well as by the use of drones, ${ }^{22}$ and information-sharing capabilities to allow third-country inter-

.europa.eu/en/publication/2020/2020-update-ngos-sar-activities\#TabPubOverview $0>$.

15 Violeta Moreno-Lax, 'The EU Humanitarian Border and the Securitization of Human Rights: The "Rescue-through-Interdiction / Rescue-without-Protection" Paradigm' (2018) 56 Journal of Common Market Studies 119.

16 Frontex, 'Longest FRONTEX coordinated operation - HERA, the Canary Islands' (Press Release, 19 December 2006) <https:/frontex.europa.eu/media-centre/news/ news-release/longest-frontex-coordinated-operation-hera-the-canary-islands-WpQls $\mathrm{c}>$.

17 Violeta Moreno-Lax, 'Protection at Sea and the Denial of Asylum' in Cathryn Costello, Michelle Foster and Jane McAdam (eds), The Oxford Handbook of International Refugee Law (Oxford University Press 2021), $483<$ https://papers.ssrn.com /sol3/papers.cfm?abstract_id=3623029>.

18 Charles Heller and Lorenzo Pezzani, 'Death by Rescue: The Lethal Effects of Non-Assistance at Sea' (Forensic Oceanography, April 2016) <https://forensic-arch itecture.org/investigation/death-by-rescue-the-lethal-effects-of-non-assistance-at-sea $>$.

19 PACE, 'The "Left-to-die Boat": Actions and Reactions', Resolution 1999 (2014) $<$ http://assembly.coe.int/nw/xml/XRef/Xref-XML2HTML-EN.asp?fileid=21024\&la ng=en $>$.

20 Council of the EU, 'EUNAVFORMED Operation Sophia: Mandate Extended until 30 September 2019' (Press Release, 29 March 2019) <www.consilium.europa .eu/en/press/press-releases/2019/03/29/eunavfor-med-operation-sophia-mandate-ex tended-until-30-september-2019/>.

21 Eugenio Cusumano, 'Migrant Rescue as Organized Hypocrisy: EU Maritime Missions Offshore Libya between Humanitarianism and Border Control' (2019) 54 Cooperation and Conflict 3, 10-12.

22 'Once migrants on Mediterranean were saved by naval patrols. Now they have to watch as drones fly over' (The Guardian, 4 August 2019) <www.theguardian.com/ world/2019/aug/04/drones-replace-patrol-ships-mediterranean-fears-more-migrant -deaths-eu>. 
ceptions of potential shipwrecks. ${ }^{23}$ Port closures and the criminalization of 'solidarity rescues' undertaken by civil society organizations are also representative of this trend. ${ }^{24}$ The overarching goal, in the words of the European External Action Service (EEAS), is to 'save lives by reducing crossings' ${ }^{25}$ so as 'to better contain the growing flows of illegal migration' across the Mediterranean. ${ }^{26}$ And this remains the underpinning rationale of the new common European approach to SAR.

This contribution will show that, in the New Pact, the emphasis is on minimizing opportunities for rescue to translate into arrival and entry into EU ports by investing in building third countries' interdiction capacity, while divesting from Member States' and EU rescue missions, and keeping SAR NGOs under close scrutiny, treating them as suspicious and potentially criminally liable for their contribution to facilitating unauthorised crossings. With this in mind, the Commission has proposed two soft-law instruments to deliver its vision: a Recommendation on how to deal with vessels owned or operated by private entities undertaking rescue activities ('SAR Recommendation' ${ }^{27}$ and Guidance on the implementation of EU rules on the facilitation of irregular migration ('Criminalisation Guidance'), ${ }^{28}$ which concentrate on the NGOs providing rescue at sea since the outbreak of the 'refugee crisis' in 2015. The other aspects of the common European

23 On the information sharing strategy of EUNAVFORMED with Libyan actors, see Letter by Paraskevi Michou, European Commission Director General for Migration and Home Affairs, to Fabrice Leggeri, Frontex Executive Director, 18 March 2019, Ref. Ares(2019)1755075 of 18 March $2019<$ www.statewatch.org/me $\mathrm{dia} /$ documents/news/2019/jun/eu-letter-from-frontex-director-ares-2019)1362751\% 20Rev.pdf $>$.

24 For an overview, see Moreno-Lax and others, 'The EU Approach on Migration in the Mediterranean' (n 1), 92-117.

25 EEAS, 'European Union Naval Force - Mediterranean Operation Sophia' (Mission Update, 15 September 2016) <https://eeas.europa.eu/sites/default/files/factshe et_eunavfor_med_en_0.pdfs.

26 EU Presidency Conclusions, EUCO 22/15, 26 June 2015, para 3 (emphasis added).

27 Commission Recommendation on cooperation among Member States concerning operations carried out by vessels owned or operated by private entities for the purpose of search and rescue activities, C(2020) 6468 final, 23 September 2020 ('SAR Recommendation') <https://ec.europa.eu/info/sites/default/files/commissio n-recommendation-_cooperation-operations-vessels-private-entities_en_0.pdf $>$.

28 Commission Guidance on the implementation of EU rules on definition and prevention of the facilitation of unauthorised entry, transit and residence, $C(2020)$ 6470 final, 23 September 2020 ('Criminalisation Guidance') <https:/ec.europa.eu/ info/sites/default/files/commission-guidance-implementation-facilitation-unautho rised-entry_en.pdf $>$. 
approach to SAR have been left inchoate in Section 4.3 of the Pact-which constitutes further evidence of where EU priorities lie.

Before delving into the details of the proposed instruments, it is worth discussing the background of the crisis environment within which the proactive containment approach has crystalized. That will provide the basis to analyse the main aspects of the common European approach to SAR in terms of rescue, disembarkation, and relocation envisaged by the Commission and allow for conclusions on the implications that ensue.

\section{Background: A 'Crisis' of our Own Making}

The origins of the boat migration 'crisis', within which the proactive containment approach has consolidated and to which the common European approach to SAR intends to respond, lie in a number of factors, starting with the drastic reduction of SAR capacity by EU coastal Member States in the Mediterranean from the 2010s, resulting in mass drownings, ${ }^{29}$ which led to the launch of the Italian Mare Nostrum Operation in 2014, ${ }^{30}$ withdrawn one year after and replaced with Frontex-coordinated border control (rather than rescue) missions Triton, ${ }^{31}$ Triton,$+{ }^{32}$ and Themis. ${ }^{33}$ Gaps in SAR capacity were met with increased deaths at sea, earning the Mediterranean the title of 'world's deadliest' frontier by the UN. ${ }^{34}$ SAR NGOs emerged as a result to try to fill those gaps in SAR provision. Although their presence was initially welcomed and their cooperation with Italian,

29 See, e.g., 'Italy Boat Sinking: Hundreds Feared Dead off Lampedusa' (BBC News, 3 October 2013) <www.bbc.com/news/world-europe-24380247>.

30 Marina Militare Italiana, Mare Nostrum Operation <www.marina.difesa.it/EN/oper ations/Pagine/MareNostrum.aspx>.

31 European Commission, 'Frontex Joint Operation "Triton" - Concerted Efforts for managing migrator flows in the Central Mediterranean', (MEMO, 31 October 2014) <www.europa-nu.nl/id/vjohgqgsbzzn/nieuws/frontex_joint_operation_trito n concerted $>$.

32 Frontex, 'Joint Operation Triton (Italy)' (Press Release, 10 October 2016) <https:// frontex.europa.eu/media-centre/news/focus/joint-operation-triton-italy--ekKaes>.

33 Frontex, 'Operation Themis (Italy)', Main Operations (Feature) $<$ https://frontex.e uropa.eu/we-support/main-operations/operation-themis-italy-/>.

34 'Mediterranean crossing still world's deadliest for migrants - UN report' (UN News, 24 November 2017) <https://news.un.org/en/story/2017/11/637162-medit erranean-crossing-still-worlds-deadliest-migrants-un-report $>$. The Commission refers to IOM data counting over 20,000 fatalities since 2014 in Recital 3, SAR Recommendation (n 27). See also IOM, Missing Migrants $<$ https://missingmigran ts.iom.int/region/mediterranean $>$. 
Maltese, and Greek coastguards run smoothly for a period of time, this changed in 2017, when the Italian government signed its MoU with Libya in February 2017,35 to jointly fight irregular migration across the Central Mediterranean route, followed by the controversial Code of Conduct for SAR NGOs in July $2017,{ }^{36}$ which among other things required them 'not to obstruct Search and Rescue operations by official Coast Guard vessels, including the Libyan Coast Guard'. ${ }^{37}$ This led to the criminalisation of the IUVENTA crew and the impoundment of their vessel in August 2017,38 after Jugend Rettet refused to sign the Code, due to several clauses being considered in breach of international law. ${ }^{39}$ Indeed, both the MoU with Libya and the Code of Conduct disregard the grave and widespread human rights abuses committed against migrants both in Libya and at sea - including by the Libyan Coastguard, which may amount to atrocity crimes, as indicated by the ICC Prosecutor in her investigation. ${ }^{40}$

The wave of criminalisation of SAR organisations and the de-legitimisation of maritime arrivals was reinforced once Salvini became Italy's Interior Minister in 2018, ${ }^{41}$ when he adopted a special security decree implementing a 'closed ports' policy, banning SAR NGOs from entering

35 'Memorandum of understanding on cooperation in the fields of development, the fight against illegal immigration, human trafficking and fuel smuggling and on reinforcing the security of borders between the State of Libya and the Italian Republic' (2 February 2017, unofficial translation) < https://eumigrationlawblog.e u/wp-content/uploads/2017/10/MEMORANDUM_translation_finalversion.doc.p df $>$.

36 (Italian) Code of Conduct for NGOs Involved in Migrants' Rescue Operations at Sea (July 2017) <www.humanrightsatsea.org/wp-content/uploads/2017/07/201707 0516-EU-Code-of-Conduct.pdf .

37 Ibid, para 9.

38 See the official website of the IUVENTA crew campaign $<$ https://iuventa-crew.org $1>$.

39 'Italy stops, inspects, NGO ship refusing to sign migrant rescue code of conduct' (EFE Italy, 2 August 2017) <www.efe.com/efe/english/life/italy-stops-inspects-ngo -ship-refusing-to-sign-migrant-rescue-code-of-conduct/50000263-3342682>.

40 ICC Prosecutor, 'Statement to the United Nations Security Council on the Situation in Libya, pursuant to UNSCR 1970 (2011)' (5 May 2020) <www.icc-cpi.int/ Pages/item.aspx? name=200505-statement-prosecutor-unsc-libya $>$. See also 'Final report of the Panel of Experts on Libya established pursuant to Security Council resolution 1973 (2011)', UN doc. S/2021/229, 8 March 2021, paras 40-46.

41 Lina Vosyliūtè and Carmine Conte, 'Crackdown on NGOs and Volunteers Helping Refugees and Other Migrants' (ReSOMA Final Synthetic Report, June 2019) $<$ www.resoma.eu/sites/resoma/resoma/files/policy_brief/pdf/Final\%20Synthetic\% 20Report $\% 20-\% 20$ Crackdown\%20on\%20NGOs\%20and\%20volunteers\%20helpin g\%20refugees\%20and\%20other\%20migrants_1.pdf $>$. 
Italian ports and disembarking survivors-regardless of Italy's obligations under EU and international law. ${ }^{42}$ This triggered a series of 'crises' whereby rescues were left incomplete, with rescue vessels left wandering for weeks or even months until voluntary, ad hoc solutions, including rerouting and relocation to other EU Member States, ${ }^{43}$ would be agreed in intergovernmental and typically secret negotiations brokered by the Commission (sometimes with Council input). The unsubstantiated belief that rescue creates a 'pull factor' that is exploited by smugglers and traffickers has fed into this dynamic, despite wide-ranging research dispelling the claim, based on data generated, not least, by Frontex and the EUNAVFORMED. ${ }^{44}$ An important detail to bear in mind is that these 'crises' have on average concerned 600 individuals at a time, which can hardly be said to overwhelm the overall asylum and return capacities of any given Member State..$^{45}$

Against this background, a first attempt to put an end to the 'ship-byship' arrangements to solve recurrent standoffs over disembarkation, particularly between Italy and Malta, was made with the Malta Declaration in September 2019, ${ }^{46}$ aiming for a structural, Europeanised solution that would make the system more stable and predictable. ${ }^{47}$ The outcome, however, was meagre and failed to bring the scheme within the EU

42 Thibault Larger, 'Matteo Salvini: Italian ports closed to migrants' (Politico, 23 December 2018) <www.politico.eu/article/matteo-salvini-italian-ports-closed-to-mi grants/>.

43 See, e.g., SOS Mediterranée, 'Aquarius instructed to sail to Spain to reach a port of safety: 629 people rescued in the Mediterranean to be disembarked in Valencia' (12 June 2018) <https://sosmediterranee.com/aquarius-instructed-to-sail-to-spain-t o-reach-a-port-of-safety-629-people-rescued-in-the-mediterranean-to-be-disembarke d-in-valencia/>.

44 Eugenio Cusumano and Matteo Villa, 'Sea Rescue NGOs: A Pull Factor of Irregular Migration?’ (MPC Policy Brief Issue 2019/22, November 2019) <https://ca dmus.eui.eu/bitstream/handle/1814/65024/PB_2019_22_MPC.pdf $>$. See also analysis and further references in Moreno-Lax and others, 'The EU Approach on Migration in the Mediterranean' (n 1), 80-81.

45 Matteo Villa and Elena Corradi, 'Migranti e EU: Cosa Serve Sapere sul Vertice di Malta' (ISPI, 20 September 2019) <www.ispionline.it/it/pubblicazione/migranti-e -ue-cosa-serve-sapere-sul-vertice-di-malta-23970>.

46 Joint Declaration of Intent on a Controlled Emergency Procedure - Voluntary Commitments by Member States for a Predictable Temporary Solidarity Mechanism ('Malta Declaration') (23 September 2019) <www.dropbox.com/s/glnukwn4 h5hw2ns/Temporary\%20Arrangements\%2023\%20September\%202019.pdf?dl=0>.

47 For an analysis, see Eleonora Frasca and Francesco Luigi Gatta, 'The Malta Declaration on Search \& Rescue, Disembarkation and Relocation: Much Ado about Nothing' (EU Migration Law Blog, 3 March 2020) < https://eumigrationlawblog.e 
legal framework, making no provision for safeguards and remedies to guarantee compliance with fundamental rights and the rule of law, instead reinforcing the trend of informal solutions and legitimising the actions by the Italian government: endorsing both the MoU with Libya and the Code of Conduct for NGOs, despite harsh criticism including by the Council of Europe Commissioner for human rights and other organisations, ${ }^{48}$ while UNHCR continued to consider Libya an unsafe place for disembarkation. ${ }^{49}$ EU support and persistent Member States' engagement with the Libyan Coastguard have been normalised as a result. ${ }^{50}$ The EU Trust Fund for Africa is a direct consequence of this approach, ${ }^{51}$ which buttresses the externalisation of SAR and the containment of maritime arrivals of seaborne migrants (the misuse of which has been denounced at the European Court of Auditors and the European Parliament). ${ }^{52}$

$\mathrm{u}$ /the-malta-declaration-on-search-rescue-disembarkation-and-relocation-much-ad o-about-nothing/>.

48 Council of Europe Commissioner for Human Rights, 'Lives saved. Rights protected: Bridging the protection gap for refugees and migrants in the Mediterranean' (June 2019) <https://rm.coe.int/lives-saved-rights-protected-bridging-the-pro tection-gap-for-refugees-/168094eb87>. See also, e.g., Amnesty International, 'EU Governments Face Crucial Decision on Shared Sea Rescue Responsibility' (3 October 2019) <www.amnesty.org/en/latest/press-release/2019/10/eu-governments -face-crucial-decision-on-shared-sea-rescue-responsibility/>.

49 UNHCR, 'Position on the Designation of Libya as a Safe Third Country and as a Place of Safety for the Purpose of Disembarkation following Rescue at Sea' (September 2020) <www.refworld.org/pdfid/5f1edee24.pdf .

50 OHCHR, "Lethal Disregard" Search and Rescue and the Protection of Migrants in the Central Mediterranean Sea' (May 2021) <www.ohchr.org/Documents/Issue s/Migration/OHCHR-thematic-report-SAR-protection-at-sea.pdf $>$.

51 Commission Decision on the establishment of a European Union Emergency Trust Fund for stability and addressing root causes of irregular migration and displaced persons in Africa, C(2015) 7293, 20 October 2015.

52 See further Global Legal Action Network ('GLAN'), 'EU Financial Complicity in Libyan Migrant Abuses'<www.glanlaw.org/eu-complicity-in-libyan-abuses >. For a critique, see Thomas Spijkerboer, 'Migration Management Clientelism: Europe's Migration Funds as a Global Political Project' (2021) Journal of Ethnic and Migration Studies DOI: 10.1080/1369183X.2021.1972567 <www.tandfonline. com/doi/full/10.1080/1369183X.2021.1972567>. 


\section{The 'New' Common European Approach to Search and Rescue}

Building on the Malta Declaration and to avoid a repeat of the 'closed ports' incidents, ${ }^{53}$ the Commission has proposed, as part of the New Pact package, a common European approach to SAR, failing, however, to provide any details on rescue and disembarkation arrangements, which, by contrast, were considered the key 'pillars' of the Malta Declaration initiative. ${ }^{54}$ The novelty lies in the solidarity relocations proposed in the draft Migration Management Regulation ('MMR'). ${ }^{55}$ But there is very little on the essentials of SAR as such. The focus, as already stated, has rather been on 'migration management' through the prevention of arrivals. ${ }^{56}$

\section{a) Normalising Disengagement}

The SAR Recommendation adds nothing to the current (underwhelming) EU rescue response in the Mediterranean, limiting itself to acknowledging that rescue is 'an obligation under international law' and highlighting that ' $[\mathrm{t}]$ he European Union is a contracting party to UNCLOS', 57 but without elaborating on the concrete repercussions of this statement. This tallies with the general remark in the New Pact, mentioned above, that SAR is 'a key element of the EU integrated border management' system to be 'implemented as a shared responsibility by Frontex and national authorities'. ${ }^{58}$ The only further specification is that Frontex 'should provide increased operational and technical support within EU competence' and 'deploy[] maritime assets to Member States to improve their capabilities', ${ }^{59}$ omitting the

53 See, e.g., Amnesty International's Letter to Ylva Johansson, Commissioner for Home Affairs, Reference: B1996, 21 May $2020<w w w . a m n e s t y . e u / w p-c o n t e n t / u p l$ oads/2020/05/B1996-Letter-to-Commission-on-pushbacks-and-port-closures.pdfs.

54 Actually, Italy has called for a return to the Malta Declaration mechanism. See 'Italy Hopeful of Reviving EU's "Malta Agreement" on Migrant Burden Sharing' (Times of Malta, 13 May 2021) <https:/timesofmalta.com/articles/view/italy-hopef ul-of-reviving-eus-malta-agreement-on-migrant-burden.871453>.

55 Proposal for a Regulation on asylum and migration management and amending Council Directive (EC) 2003/109 and the proposed Regulation (EU) XXX/XXX [Asylum and Migration Fund], $\operatorname{COM(2020)~} 610$ final, 23 September 2020 ('Migration Management Regulation' or 'MMR').

56 SAR Recommendation (n 27), paras 1 and 2(b).

57 Ibid, Recital 1.

58 'New Pact on Migration and Asylum' (n 2), 13.

59 Ibid (emphasis added). 
fact that Frontex has no explicit mandate to proactively engage in SAR. In fact, the agency has been confronted with repeated accusations for failure to respond to distress calls, ${ }^{60}$ if not directly contributing to push-backs, ${ }^{61}$ and ignoring 'instructions to move ... outside [the relevant mission's] operational area' for the purpose of rendering assistance to migrant boats, in a bid to avoid coming into contact with them and triggering rescue obligations in their regard. ${ }^{62}$ This has triggered several investigations by its own Management Board, ${ }^{63}$ OLAF, ${ }^{64}$ the EU Ombudsman, ${ }^{65}$ and a special Working Group of the European Parliament, ${ }^{66}$ while several legal actions are pending against the agency. ${ }^{67}$

60 Alarm Phone, 'Coordinating a Maritime Disaster: Up to 130 People Drown off Libya' (22 April 2021) < https://alarmphone.org/en/2021/04/22/coordinating-a-mar itime-disaster-up-to-130-people-drown-off-libya/?post_type_release_type=post $\& \mathrm{fbc}$ lid=IwAR1rzZq6YGZTvsjTfGgMMn7QxuKkDQCU-L3X8biOblwCNo3-15ToWiB $7 \mathrm{uWk}>$.

61 ECRE, 'Med: Investigations Reveal Frontex' Complicity in Interceptions and Returns to Horrors in Libya' (Weekly Bulletin, 30 April 2021) <https://mailchi.mp/ ecre/ecre-weekly-bulletin-30042021? e=2bf31e028b\#med $>$. Regarding the Aegean, see 'EU Border Agency Frontex Complicit in Greek Refugee Pushback Campaign' (Der Spiegel, 23 October 2020) <www.spiegel.de/international/europe/eu-border-a gency-frontex-complicit-in-greek-refugee-pushback-campaign-a-4b6cba29-35a3-4d 8c-a49f-a12daad450d7>; and Matina Stevis-Gridneff, 'E.U. Border Agency Accused of Covering Up Migrant Pushback in Greece' (New York Times, 26 November 2020) <www.nytimes.com/2020/11/26/world/europe/frontex-migrants-pushback-g reece.html>.

62 Letter by Klaus Rösler, Frontex Director of Operations, to Giovanni Pinto, Italian Director of the Border Police, Ref. 19846/25.11.2014<https://s3.documentcloud.o rg/documents/3531242/Rosler-Pinto-Frontex-Letter-2014.pdf $>$.

63 'Conclusions of the Management Board's meeting on 5 March 2021 on the report of its Working Group on Fundamental Rights and Legal Operational Aspects of Operations in the Aegean Sea' (Frontex Management Board Updates, 5 March 2021) <https://frontex.europa.eu/media-centre/management-board-updates/conclu sions-of-the-management-board-s-meeting-on-5-march-2021-on-the-report-of-its-w orking-group-on-fundamental-rights-and-legal-operational-aspects-of-operations-in -the-aegean-sea-aFewSI>.

64 Nikolaj Nielsen, 'EU Anti-fraud Office Launches Probe into Frontex' (EU Observer, 11 January 2021) <https://euobserver.com/migration/150574>.

65 EU Ombudsman, 'Ombudsman Opens Inquiry to Assess European Border and Coast Guard Agency (Frontex) "Complaints Mechanism”' (12 November 2020) $<$ www.ombudsman.europa.eu/en/news-document/en/134739>.

66 European Parliament, 'Report on the Fact-finding Investigation on Frontex Concerning Alleged Fundamental Rights Violations' (14 July 2021) <www.europarl.e uropa.eu/cmsdata/238156/14072021\%20Final\%20Report\%20FSWG_en.pdf .

67 Front-Lex and Legal Centre Lesvos, 'Preliminary Action Pursuant to Article 265 TFEU' (15 February 2021) <www.statewatch.org/news/2021/april/pushbacks-from- 
Instead of clarifying SAR obligations or increasing rescue assets in the Mediterranean, the SAR Recommendation relies on the rescue capacity stemming from 'the ... involvement of private and commercial vessels', including those operated by NGOs, praising the 'significant contributions from coastal States' and Frontex, ${ }^{68}$ but without calling on them for additional efforts, despite a reference to the explicit request by the European Parliament to that effect, and a direct allusion to the maritime conventions 'obligat[ing] contracting parties to participate in the development of SAR services and to take urgent steps to ensure that the necessary assistance is provided to any person ... in distress at sea' ${ }^{69}$ No additional assets or resources are pledged or organised. The only provision made is for an Interdisciplinary Contact Group of relevant stakeholders, including Frontex, SAR NGOs, academics, and international organisations, to develop best practices, exchange information and reinforce cooperation between flag and coastal Member States ${ }^{70}$ - which, however, since inception in March 2021, has been accused of failing to meet its own transparency requirements and discharge its mandate as originally intended. ${ }^{71}$

\section{b) Policing Humanitarianism}

At the same time, the SAR Recommendation contains a veiled critique of NGO rescues. First, the SAR Recommendation embraces the 'pull factor' rhetoric when stating that it is essential to avoid a situation in which migrant smuggling or human trafficking networks ... take advantage of the rescue operations conducted by private vessels' ${ }^{72}$ It is unclear whether the necessary implication is that rescue should not be performed, if it risks jeopardising 'effective migration management' as defined by the

greece-to-turkey-ombudsman-s-report-highlights-obstruction-of-investigations/>. See also Statewatch, 'EU: Legal Actions Pile up against Frontex for Involvement in Rights Violations' (23 February 2021) <www.statewatch.org/news/2021/february/e u-legal-actions-pile-up-against-frontex-for-involvement-in-rights-violations/> .

68 SAR Recommendation (n 27), Recitals 4-5.

69 Ibid, Recitals 6 and 10.

70 Ibid, Recitals 15-16 and paras 1-2.

71 Statewatch, 'Mediterranean: European Contact Group on Search and Rescue Failing to Meet Transparency Requirements' (23 April 2021) <www.statewatch.org/ne ws/2021/april/mediterranean-european-contact-group-on-search-and-rescue-failing -to-meet-transparency-requirements/>.

72 SAR Recommendation (n 27), Recital 9. 
Commission, ${ }^{73}$ which laments that 'continued disembarkations ... have direct consequences on [Member States'] migration management systems and place increased and immediate pressure on [them] ${ }^{\prime}{ }^{74}$

Be it as it may, the foreseeable impact of the SAR Recommendation, rather than increasing SAR capacity in the Mediterranean, may well be the opposite by subjecting SAR NGO vessels to strict scrutiny, using 'safety of navigation' as an excuse to police their activity. ${ }^{75}$ Several measures, which in themselves constitute forms of criminalisation of humanitarianism in the broad sense, ${ }^{76}$ are proposed in the SAR Recommendation for this purpose. On the premise that SAR NGOs may conduct 'consecutive rescue operations before disembarking [survivors]' and act on their own motion, ${ }^{77}$ rather than at the behest of a Maritime Rescue Coordination Centre, with that 'trigger[ing] specific operational needs of enhanced coordination' with the authorities concerned, ${ }^{78}$ the Commission feels this requires special rules of control, even though this behaviour is in conformity with international law. ${ }^{79}$

Because SAR NGOs may conduct large and complex rescues, there appears to be an assumption that this may give rise-per se and without further substantiation-to 'public policy, including safety' concerns, justifying a need to closely police that SAR NGO vessels are 'suitably registered and properly equipped to meet the relevant safety and health requirements associated with [their] activity'. ${ }^{80}$ There are, however, no instances of any SAR NGO vessel having failed to comply with registration and safety of navigation rules in the past-all prosecutions on these grounds have ended in acquittal. ${ }^{81}$ It is also telling that the same level of scrutiny does not apply to the Libyan Coastguard and similar actors with which the

73 Ibid, para 1; and 'New Pact on Migration and Asylum' (n 2), 14.

74 SAR Recommendation (n 27), Recital 13.

75 'New Pact on Migration and Asylum' (n 2), 14. As an indication, see questions referred in CJEU, Case C-15/21 Sea-Watch (pending).

76 Sergio Carrera, Valsamis Mitsilegas and Jennifer Allsopp, Policing Humanitarianism (Hart Publishing 2019).

77 SAR Recommendation (n 27), Recital 8.

78 Ibid, Recital 11.

79 For a detailed discussion, see Violeta Moreno-Lax, Daniel Ghezelbash and Natalie Klein, 'Between Life, Security and Rights: Framing the Interdiction of "Boat Migrants" in the Central Mediterranean and Australia' (2019) 32 Leiden Journal of International Law 715.

80 SAR Recommendation (n 27), Recital 12.

81 Moreno-Lax and others, 'The EU Approach on Migration in the Mediterranean' (n 1), Annex Table I. 
coastal Member States and the EU routinely cooperate, including private merchant vessels. ${ }^{82}$ And no attention is paid to the fact that oftentimes the complexity of rescues is compounded by the refusal to allow disembarkation at safe ports on the EU side. ${ }^{83}$

In addition, the rules in the maritime Conventions on safety of navigation and rescue capacity for the performance of SAR duties are primarily addressed to the State parties' fleets. ${ }^{84}$ They primarily concern State-run rescue services rather than private vessels, which are supposed to only sporadically engage in SAR actions-on the assumption that coastal States fulfil their duties and run effective SAR services within their rescue zones. The proposal by the Commission to turn the scheme upside-down and enforce the rules on NGO vessels, while official SAR services are withheld, ${ }^{85}$ is inadequate. It amounts to a reversed stoppel argument used to obstruct NGO interventions. Not only are States not being called upon to observe their SAR obligations, but they are seemingly encouraged to 'transfer' them to the NGO sector and then police them, as a way to impede their action and foreclose unwanted migration flows.

In the same vein, the Recommendation mentions the Italian Code of Conduct, and appears to imply that it may provide a model for the cooperation and coordination framework to be established by the Interdisciplinary Contact Group, for the purposes of 'increase[ing] safety at sea' and 'monitor[ing] and verify[ing] compliance with standards for safety at sea as well as the relevant rules on migration management'. ${ }^{86}$ To that end, the framework should specifically aim to provide 'appropriate information as regards the operations and the administrative structure' of SAR NGOs, ${ }^{87}$

82 Jean-Pierre Gauci, 'When Private Vessels Rescue Migrants and Refugees: A Mapping of Legal Considerations' (British Institute of International and Comparative Law, November 2020) <www.biicl.org/documents/124_private_vessels_research.p df $>$.

83 Izzy Ellis, 'In the News: COVID-19 Port Closures Leave Migrants Stranded at Sea' (The New Humanitarian, 13 April 2020) <www.thenewhumanitarian.org/news/202 0/04/13/mediterranean-italy-malta-migrants-coronavirus $>$.

84 Convention on the Law of the Sea 1833 UNTS 3 ('UNCLOS'), Art 98; International Convention for the Safety of Life at Sea 1184 UNTS 278 ('SOLAS Convention'); International Convention on Maritime Search and Rescue 1405 UNTS 119 ('SAR Convention').

85 E.g. Chantal Da Silva, 'Italy, Malta and Libya Slow to React to Deadly Shipwreck, Analysis Finds' (Euronews, 4 May 2021) <www.euronews.com/2021/05/04/italy-ma lta-libya-slow-to-react-to-deadly-shipwreck-analysis-finds $>$.

86 SAR Recommendation (n 27), Recitals 14-16 and para 2.

87 Ibid, Recital 15. 
hence Europeanising policing practices that de facto restrict, rather than facilitate, rescue activities.

The proposed common European approach to search and rescue, therefore, encloses a paradox: it relies on the enhanced SAR capacity represented by private vessels operated by NGOs, while raising suspicion of their undertakings, which it attempts to control, police, and may ultimately supress. This is particularly evident from the manner in which the Guidance on the criminalisation of humanitarian assistance has been framed.

\section{c) (Not Entirely De-)Criminalising Humanitarian Assistance}

Despite criticism by the UN Office on Drugs and Crime (UNODC), i.e. the body in charge of overseeing the correct application of the UN Protocol against Migrant Smuggling (which the EU ratified in 2006), ${ }^{88}$ making clear that the behaviour that may be criminalised is the facilitation of irregular entry mediating financial benefit and alerting that 'even if the Protocol does not prevent States from creating [other] criminal offences outside its scope ... it does not seek and cannot be used as the legal basis for the prosecution of humanitarian actors' ${ }^{89}$ the response by the Commission has been equivocal. While it has expressed the view that Article 1 of the Facilitation Directive must be interpreted so that 'humanitarian assistance that is mandated by law [presumably including rescue at sea] cannot and must not be criminalised', ${ }^{90}$ the Guidance fails to provide examples of what should be understood as 'humanitarian assistance' or when should it be considered as 'mandated by law'. Then, the Commission states that 'the criminalisation of NGOs ... that carry out [SAR] operations at sea ... amounts to a breach of international law and therefore is not permitted by EU law', but it caveats the provision to cover only rescue operations conducted 'while complying with the relevant legal framework', ${ }^{91}$ which allows for speculation.

88 UN Protocol against the Smuggling of Migrants, 2241 UNTS 507; Council Decision 2006/616/EC of 24 July 2006 on the conclusion, on behalf of the European Community, of the Protocol Against the Smuggling of Migrants by Land, Sea and Air, [2006] OJ L 262/24.

89 Criminalisation Guidance (n 28), 3.

90 Ibid, para 4(i), referring to Council Directive 2002/90/EC of 28 November 2002 defining the facilitation of unauthorised entry, transit and residence ('Facilitation Directive'), [2002] OJ L 328/17.

91 Criminalisation Guidance (n 28), para 4(ii). 
Quite controversially, the Commission claims that '[e]veryone involved in search and rescue activities must observe the instructions received from the coordinating authority when intervening in search and rescue events', ${ }^{92}$ disregarding recent incidents of orders provided to stand-by or to collaborate with the Libyan Coastguard in contravention of international obligations flowing from the right to life or the prohibition of refoulement. ${ }^{93}$ Conversely, due to the prohibition on any State to claim sovereignty over the high seas, no jurisdictional powers, different from those explicitly recognized by the UN Convention on the Law of the Sea (UNCLOS) or other relevant treaties, can validly be established to deliver orders with legal effect to foreign ships. ${ }^{94}$ Freedom of navigation and the rule of exclusive flag-state jurisdiction support this interpretation. ${ }^{95}$ What is more, in the specific context of SAR interventions, the Safety of Life at Sea Convention (SOLAS) makes clear that no 'other person ... shall ... prevent or restrict the master of the ship from taking or executing any decision which, in the master's professional judgement, is necessary for safety of life at sea'. ${ }^{96}$ Such level of discretion is essential to respond promptly and adequately to rapidly changing circumstances. And, as regards the content of SAR instructions by rescue coordination authorities, these cannot be such as to contravene the purpose of the SAR regime-which is to preserve human life at sea. Neither can they violate human rights. ${ }^{97}$ In such situations, shipmasters have what has been called a 'right to obey international law'.98

The Guidance fails to clarify the specific conduct to be punished and the conditions under which it should be prosecuted-something that cannot be authoritatively defined in a non-binding Commission Recommendation, but which is required for compliance with the principle of legality of offences under Article 49 of the Charter of Fundamental Rights. The final assessment rests with the judicial authorities of the Member States. They are the ones who will (ex post facto) 'have to strike the right balance

92 Ibid, 7 (emphasis added).

93 Charles Heller and Lorenzo Pezzani, 'Mare Clausum: Italy and the EU's Undeclared Operation to Stem Migration across the Mediterranean' (Forensic Oceanography, May 2018) <https://content.forensic-architecture.org/wp-conte nt/uploads/2019/05/2018-05-07-FO-Mare-Clausum-full-EN.pdfs.

94 UNCLOS, Art 89.

95 UNCLOS, Arts 90 and 92(1).

96 SOLAS, Annex c V reg 34-1 (emphasis added).

97 UNCLOS, Arts 2(3) and 87(1).

98 Massimo Starita, 'The Duty to Rescue at Sea and the Shipmaster's "Right to Obey" (International) "Law"' (2019) 7 Diritti umani e diritto internazionale 5. 
between the different interests and values at play'99 — as if the (customary international legal) duty to rescue or the absolute principle of non-refoulement admitted such a balancing against the migration management interests of the Union and the Member States.

The Guidance also explains the discrepancy in the 'for profit' motive between EU law and the UN Protocol by the dual purpose of the Facilitation Directive and related instruments, which is not just to combat organised crime-the primary object of the UN instrument-but also to combat irregular migration as such. By this logic, 'the non-inclusion of the purpose of gain in the basic definition of the offence of facilitation of entry and transit would not be in contrast with the definition of the UN Protocol, but rather [constitute] an expression of the additional (and broader) objective of fighting against irregular migration' in the EU context. ${ }^{100}$ The resulting risk of over-criminalisation is, however, left unaddressed.

The only policy recommendation made by the Commission is simply to 'invite' Member States 'to use the possibility provided for in Article 1(2) of the Facilitation Directive' of exonerating humanitarian assistance from criminalisation. ${ }^{101}$ This means that a matter of EU legality (and its compatibility with international law) is left unresolved and relegated to an issue of domestic implementation and policy preference that may ultimately have to be settled by Member State Courts 'on a case-by-case basis'. ${ }^{102}$ In consequence, the practices of policing and criminalisation of SAR NGOs witnessed since 2017 may endure. ${ }^{103}$ It will only be in the Courts that their activities, as humanitarian actors and human rights defenders, may eventually be de-criminalised. But the strategy of 'persecution by prosecution', used in Italy and Greece against Sea-Watch, Proemaid, or Team Humanity, ${ }^{104}$ can and will foreseeably continue under the terms

99 Criminalisation Guidance (n 28), 6.

100 Angelo Marletta, 'The Commission 'Guidance' on Facilitation and Humanitarian Assistance to Migrants' (EU Law Analysis Blog, 29 September 2020) $<$ http://e ulawanalysis.blogspot.com/2020/09/the-commission-guidance-on-facilitation.ht $\mathrm{ml}>$.

101 Criminalisation Guidance (n 28), 8 (emphasis added).

102 Ibid, para 4(iii).

103 OMCT, 'Europe: New Report Highlights Increased Criminalisation against Migrants’ Rights Defenders' (15 November 2021) <www.omct.org/en/resources/ne ws-releases/europa-nuevo-informe-alerta-sobre-el-incremento-de-la-criminalizaci $\% \mathrm{C} 3 \% \mathrm{~B} 3 n$-contra-defensor-s-de-personas-migrantes $>$.

104 'Sea-Watch Captain Rackete Faces Italian Prosecutor over Migrant Rescue' (France24, 18 July 2019) <www.france24.com/en/20190718-germany-italy-liby a-sea-watch-captain-prosecutor-migrant-rescue-carla-rackete>; Niki Kitsantonis, 
of the Criminalisation Guidance. ${ }^{105}$ Only legislative action would ensure alignment with the requirements of legal certainty, legitimacy, and proportionality, guaranteeing compliance with the principle of legality and the rule of law.

\section{Disembarkation and Relocation}

Regarding disembarkation, there is no proposal as part of the common European approach to SAR to clarify where survivors should be taken when rescued within operations not coordinated by Frontex (which is the only scenario regulated by the EU Maritime Surveillance Regulation, ${ }^{106}$ to which the Commission proposals make no reference). Rather than attempting a clarification, the Commission alludes to 'strengthen[ed] cooperation with countries of origin and transit to prevent ... irregular crossings, including through tailor-made Counter Migrant Smuggling Partnerships with third countries'. ${ }^{107}$ Although no direct mention is made of Libya, Turkey or Morocco, these are the main countries of provenance of rescued persons disembarked in the EU. ${ }^{108}$ It is striking that there is no discussion of the human rights implications of collaboration with these countries and that the proposal completely disregards the EU's and the Member

'Volunteers Who Rescued Migrants Are Cleared of Criminal Charges in Greece' (New York Times, 7 May 2018) <www.nytimes.com/2018/05/07/world/europe/gr eece-migrants-volunteers.html>; GLAN, 'Greece's Crackdown on Humanitarian Organisations' (April 2019) <www.glanlaw.org/salamaldeen $>$.

105 See FRA, 'June 2021 Update - Search and Rescue (SAR) operations in the Mediterranean and fundamental rights' (18 June 2021) <https://fra.europa.eu/e n/publication/2021/june-2021-update-ngo-ships-sar-activities $>$. For an ongoing case, see Helena Smith, 'On Trial for Saving Lives: The Young Refugee Activist Facing a Greek Court' (The Guardian, 14 November 2021) <www.theguardian.co $\mathrm{m} /$ world/2021/nov/14/on-trial-for-saving-lives-the-young-refugee-activist-facing-a -greek-court $>$.

106 Regulation (EU) No 656/2014 of 15 May 2014 establishing rules for the surveillance of the external sea borders in the context of operational cooperation coordinated by the European Agency for the Management of Operational Cooperation at the External Borders of the Member States of the European Union, [2014] OJ L 189/93.

107 'New Pact on Migration and Asylum' (n 2), 14.

108 UNHCR, Operational Data Portal: Mediterranean (November 2021) <https://dat a2.unhcr.org/en/situations/mediterranean>. 
States' own extraterritorial obligations vis-à-vis third-country nationals, ${ }^{109}$ including concerning the right to leave any country including one's own, the right to seek asylum, and the right to protection from ill-treatment as well as the prohibitions of collective expulsion and refoulement that remain relevant at sea. ${ }^{110}$

\section{a) Compulsory Solidarity?}

It is only if (and once) disembarkation takes place in an EU Member State that there is a specific system of solidarity relocations, which may be activated as part of the new provisions contained in the proposed Migration Management Regulation ('MMR'). As explained by Maiani, ${ }^{111}$ the system can work in 'basic' mode, 'pressure' mode, or 'crisis' mode. In its basic variant, designed to replace the current ad hoc solutions, ${ }^{112}$ the Commission assesses, in its yearly Migration Management Report, ${ }^{113}$ whether a Member State is faced with 'recurring [maritime] arrivals' following rescue operations and determines its solidarity needs, ${ }^{114}$ in terms of relocations and other contributions potentially taking the form of 'return sponsorships' or capacity-building measures. ${ }^{115}$ The other Member States are then 'invited' to notify the 'contributions they intend to make'. ${ }^{116}$ If offers are sufficient, the Commission adopts a 'solidarity pool'. ${ }^{117}$ If not, it will convene a 'Solidarity Forum' and ask Member States to adjust their pledges. ${ }^{118}$ If the offer still falls 'significantly short' of the needs,

109 European Parliament, Resolution of 19 May 2021 on Human Rights Protection and the EU External Migration Policy (2020/2116(INI)) <www.europarl.europa. eu/doceo/document/TA-9-2021-0242_EN.html>, relying on Violeta Moreno-Lax, 'EU External Migration Policy and the Protection of Human Rights', PE 603.512 (European Parliament 2020) <www.europarl.europa.eu/RegData/etudes/IDAN/2 020/603512/EXPO_IDA(2020)603512_EN.pdf $>$.

110 ECtHR, Hirsi Jamaa and Others v. Italy, Appl. 27765/09, 23 February 2012. See also HRC, A.S. and Others v. Italy, Comm. 3042/2017, CCPR/C/130/D/ 3042/2017, 27 January 2021; and A.S. and Others v. Malta, Comm. 3043/2017, CCPR/C/128/D/3043/2017, 27 January 2021.

111 See Francesco Maiani's chapter in this volume.

112 MMR (n 55), Arts 47-49.

113 Ibid, Art 6(4).

114 Ibid, Art 47(1).

115 Ibid, Art 45.

116 Ibid, Art 47(3)-(4).

117 Ibid, Art 48(1) and 49.

118 Ibid, Art 46 and 47(5). 
the Commission will adopt an implementing act, ${ }^{119}$ identifying relocation targets for each Member State according to a distribution key, weighing total population and total GDP. ${ }^{120}$ Member States may react by offering other contributions instead, provided that this is considered 'proportional'. If the relocations offered still fall $30 \%$ short of the identified needs, each Member State will be obliged to meet at least $50 \%$ of their quota via relocations or return sponsorships. ${ }^{121}$ If the solidarity pool risks being exhausted, the Commission can revise it and set out additional relocations, which, however, may be 'capped to 50\%' of the amount initially foreseen. ${ }^{122}$ If these, too, become insufficient, then the 'pressure' or 'crisis' mode may be activated. ${ }^{123}$

The relocation scheme can also be triggered by a 'request for solidarity support' from the Member State faced with repeated maritime arrivals. ${ }^{124}$ In such cases, the Commission will draw on the solidarity pool and coordinate implementation of the solidarity measures 'for each disembarkation or group of disembarkations' 125 — which may replicate the current 'ship-byship' formulas. It is then for the Commission, alongside Frontex and EA$\mathrm{SO}$, 'to draw up a list of eligible persons to be relocated', indicating their distribution amongst the contributing Member States, taking account of their nationalities and any 'meaningful links' with the country of relocation, but giving priority to vulnerable persons. ${ }^{126}$

From this brief overview the overly complex nature of the system proposed becomes visible and a number of shortcomings readily detected. First of all, it is unclear what happens if Member States fail to engage with the SAR Solidarity Response Plan, ${ }^{127}$ if they persist in their defection or do not comply with the Commission indications. What if there are conflicts between Member States or if they contest the way in which their quotas have been calculated? There are no conciliation procedures or sanctions envisaged in such cases. It is also unclear how long the Solidarity Forum may deliberate for and under which rules; this may defeat the objective of 'rapid' relocations, which may, in turn, translate into situations where

119 Ibid, Art 48.

120 Ibid, Art 54.

121 MMR Memorandum (n 55), 19.

122 Ibid.

123 MMR (n 55), Arts 49(3) and 50-53.

124 Ibid, Art 49(1).

125 Ibid (emphasis added).

126 MMR (n 55), Art 49(2).

127 Ibid, Art 47(4) and Annex I. 
disembarkations are withheld indefinitely. The system depends on constant negotiation and relies on an amount of good faith and mutual trust unseen between the Member States so far. ${ }^{128}$ We also do not know how concurrent situations of 'recurring arrivals', 'migratory pressure' or 'crisis' sparking simultaneously in different Member States will be reconciled. The Commission promises 'reductions' of up to $10 \%$ of the quotas of contributing Member States in certain situations, ${ }^{129}$ but it remains silent on the coordination of concurrent emergencies.

Overall, it seems unrealistic to expect Member States to cede the required power to the Commission to force their hand into accepting relocations of disembarked migrants. A repeat of the legal proceedings against the Visegrad countries regarding the 2015 relocation scheme cannot be discarded. ${ }^{130}$ The proposal in fact concentrates the power to make all the key decisions in the hands of the Commission, to decide what the solidarity needs are and how these should be distributed; whether Member States are confronted with 'recurring arrivals', 'pressure' or a 'crisis'; how solidarity contributions should be calculated and which shape they need to take. Yet, it is unclear how much more predictable, swift or foreseeable this system will be compared to the current ad hoc arrangements.

\section{b) Limitless Defection Possibilities}

The situation is exacerbated by the new rules on force majeure, contained in the draft crisis and forced majeure Regulation ('CFMR'), ${ }^{131}$ which the Com-

128 Violeta Moreno-Lax, 'Mutual (Dis-)Trust in EU Migration and Asylum Law: The Exceptionalisation of Fundamental Rights' in Maribel González Pascual and Sara Iglesias Sánchez (eds), Fundamental Rights in the EU Area of Freedom, Security and Justice (Cambridge University Press 2021), 77.

129 MMR (n 55), Art 52(5).

130 CJEU, Joined Cases C-643/15 and C-647/15 Slovakia and Hungary v. Council [2017] ECLI:EU:C:2017:631; and Joined Cases C-715/17, C-718/17 and C-719/17 Commission v. Poland [2020] ECLI:EU:C:2020:257. For analysis and full references on the Relocation scheme, see Elspeth Guild, Cathryn Costello and Violeta Moreno-Lax, 'Implementation of the 2015 Council Decisions establishing provisional measures in the area of international protection for the benefit of Italy and of Greece', PE 583.132 (European Parliament 2017) <www.europarl.eu ropa.eu/RegData/etudes/STUD/2017/583132/IPOL_STU(2017)583132_EN.pdfs.

131 Proposal for a Regulation addressing situations of crisis and force majeure in the field of migration and asylum, $\operatorname{COM}(2020) 613$ final, 23 September 2020 ('CFMR'). 
mission proposal fails to define. While crisis scenarios are characterised by a 'mass influx of third-country nationals ... arriving irregularly in a Member State or disembarked on its territory following search and rescue operations, being of such a scale ... and nature that it renders the Member State's asylum, reception or return system non-functional', ${ }^{132}$ force majeure has not been specified. The Preamble of the proposed instrument relates generally to 'abnormal and unforeseeable circumstances outside [Member States'] control the consequences of which could not have been avoided in spite of all due care' and it alludes to the COVID-19 pandemic and lessons to be learnt from it. ${ }^{133}$ But rather than condemning the violations witnessed throughout this period ${ }^{134}$ - vaguely referring to the unlawful suspension of the right to asylum by the Greek authorities in March 2020 as a 'political crisis', ${ }^{135}$ the Commission proposes to entrench them as valid derogations from the applicable rules-ignoring the impact that these will have on absolute human rights, like the prohibition of ill-treatment (including refoulement), which do not allow for proportionality reasoning or any limitations or derogations whatsoever.

An extra complication stems from the new force majeure framework, which can be triggered on a simple notification. ${ }^{136}$ What will happen if a majority of Member States unilaterally declared themselves to be faced with a force majeure situation, such as an additional wave of COVID-19 infections? The current proposal allows them to do so without any democratic or legal oversight by the European Parliament or the Commission. This will put on hold solidarity mechanisms for months and exempt Member States from Dublin transfers for an unspecified period of time, since there is no deadline applicable to the length of the force majeure situation. ${ }^{137}$ This can paralyse the system and lead to a legalised form of fragmentation, which could lead to de facto de-harmonization of the existing legal and pol-

132 Ibid, Art 1(2).

133 Ibid, Recital 7 and CFMR Memorandum (n 131), 4 and 9-11.

134 E.g., UNHCR, 'UNHCR issues recommendations for EU to ensure refugee protection during the pandemic and beyond' (Press Release, 1 July 2020) $<$ www.unhcr.org/news/press/2020/7/5efb7e544/unhcr-issues-\%20recommend ations-eu-ensure-refugee-protection-during-pandemic.html $>$.

135 CFMR Memorandum (n 131), 9. Cf. UNHCR, 'UNHCR statement on the situation at the Turkey-EU border' (2 March 2020) <www.unhcr.org/news/press/2020 /3/5e5d08ad4/unhcr-statement-situation-turkey-eu-border.html $>$.

136 CFMR (n 131), Art 7(1).

137 Ibid, Arts 3(4) and 7(2). 
icy framework, unwalking the steps towards a common European system in this field. ${ }^{138}$

\section{c) From Win-Win to Lose-Lose Outcomes}

While it is open to discussion who the winners of this scheme will be, there are some clear losers. The implications for applicants and the beneficiary Member States need to be considered in some detail. Although one may think that relocations will be a 'good thing' for the individuals concerned, it is striking that their agency, voice, and preferences will not be taken into account. Although they will be able to oppose a relocation decision (on the same limited grounds they could challenge a Dublin transfer ${ }^{139}$ ), it is unclear the degree to which extended family links, support networks, and other relevant connections will be taken into consideration, in light of the 'swiftness' with which the pre-entry screening and relocation procedures are supposed to take place. The 'meaningful links' that need to be factored into relocation decisions have not been defined in the proposed Regulation, ${ }^{140}$ beyond the allusion to 'diploma[s] or qualification[s] issued by an educational institution established by a Member State' and some 'targeted extensions of the family definition'. ${ }^{141}$ The fact that some relocations (or 'return sponsorships') will, therefore, be arranged against their will entrench, rather than reduce, possibilities for supposed abuses and boost the much-despised 'secondary movements' within the Schengen area. ${ }^{142}$ Another issue the Commission fails to address is the potential incompatibility of these arrangements with Article 3 of the Refugee Convention, ${ }^{143}$ which forbids discrimination amongst refugees. This system, however, singles out maritime rescuees on the basis of their mode of arrival to the prospective country of refuge, putting them at a potential disadvantage on grounds unrelated to their protection needs.

There are also significant hidden costs for beneficiary Member States, who will need to undertake substantial processing of SAR arrivals before relocation can be pursued, including for pre-entry screening purposes,

138 See further Philippe De Bruycker's contribution to this collection.

139 CJEU, Case C-163/17 Jawo [2019] ECLI:EU:C:2019:218.

140 MMR (n 55), Art 49(2). Cf MMR, Art 2.

141 Ibid, Recital 50 and MMR Memorandum (n 55), 24 (emphasis added).

142 See Daniel Thym's chapter in this volume.

143 Convention relating to the Status of Refugees, 189 UNTS 150. 
entailing health and security checks, ${ }^{144}$ which may exclude applicants from relocation ${ }^{145}$; for the registration of asylum applications ${ }^{146}$; to carry out some form of abbreviated Dublin processing, at least, to establish whether family criteria may render the Member State of disembarkation responsible for the potential candidate ${ }^{147}$; and regarding the border procedure, if persons fall within its remit, ${ }^{148}$ since this also disqualifies them from relocation. ${ }^{149}$

Against this background, the extent to which relocations can be made swift remains doubtful and whether Member States in 'pressure' or 'crisis' situations will be able to adequately cope, even on account of the extended deadlines for registration and transfers under the applicable modes of operation is uncertain. ${ }^{150} \mathrm{Also}$, and most importantly, there are no guarantees against defection on the part of fellow Member States. In cases of non-compliance, the beneficiary Member State will, in fact, be 'stuck' with the persons concerned.

\section{Concluding Remarks: Towards a Thousand Little Morias}

All in all, the Commission's plan for a new common European approach to search and rescue leaves much to be desired. It structuralises the current (mal)practices, including those whose legitimacy and legality have been challenged in national and European Courts. ${ }^{151}$ This, I fear, will create more problems than will solve.

144 Proposal for a Regulation introducing a screening of third country nationals at the external borders, $\operatorname{COM}(2020)$ 612, 23 September 2020 ('pre-entry screening proposal'), Arts 6(6), 9 and 11. For analysis, see Lyra Jakulevičienè's contribution to this collection.

145 MMR (n 55), Art 57(2) and MMR Memorandum (n 55), 12.

146 Pre-entry screening proposal (n 144), Arts 10 and 14(6).

147 MMR (n 55), Art 57(3).

148 Amended Proposal for a Regulation establishing a common procedure for international protection in the Union and repealing Directive 2013/32/EU, $\operatorname{COM}(2020)$ 611, 23 September 2020, Art 41. See further Jens Vedsted-Hansen's chapter in this volume.

149 MMR (n 55), Art 45(1)(a).

150 CFMR (n 131), Arts 4-6 and 7-9.

151 See, e.g., GLAN, 'Migration and Border Violence Stream, containing a summary of the legal actions undertaken by the organisation' <www.glanlaw.org/migratio nandborders $>$. 
Rescue in the New Pact has been designed as an exception to the general rule of containment of unwanted arrivals, and unauthorised crossings as a risk to be avoided as much as possible. Within this framework, the EU will 'support capacity building ... help[ing] partner countries manage irregular [flows]', ${ }^{152}$ framing maritime intervention as a function of border management. When assisting third countries, the EU will indeed focus on 'strengthening capacities for border management, including by reinforcing their search and rescue capacities at sea'. ${ }^{153}$ Rescue will thereby be further securitised, ${ }^{154}$ configured as a form of 'sovereign capture' that becomes undistinguishable from interdiction, ${ }^{155}$ used to spare the dangers of deadly crossings, to be performed pre-emptively to avoid loss of life, but, at the same time, in a way that impedes access to protection in Europe. ${ }^{156}$ Pull-backs, detention and repression by partner States will thus become further normalised, ${ }^{157}$ if not legitimised as a means within the 'targeted migrant smuggling partnerships' the EU is to conclude with third countries, ${ }^{158}$ regardless of their human rights implications-which are nowhere mentioned in the New Pact.

Even upon disembarkation the possibility of a thousand little Morias proliferating cannot be excluded. ${ }^{159}$ The combination of pre-entry screening arrangements, border procedures, and complex solidarity relocations

152 'New Pact on Migration and Asylum' (n 2), 20.

153 Ibid (emphasis added).

154 Daniel Ghezelbash and others, 'Securitization of Search and Rescue at Sea: The Response to "Boat Migration" in the Mediterranean and Offshore Australia' (2018) 67 International and Comparative Law Quarterly 315.

155 Polly Pallister-Wilkins, 'Humanitarian Rescue/Sovereign Capture and the Policing of Possible Responses to Violent Borders' (2017) 8 Global Policy 19. See also Moreno-Lax, 'The EU Humanitarian Border and the Securitization of Human Rights' (n 15).

156 A prime example of this practice is offered by ECtHR, S.S. and Others $v$. Italy, Appl. 21660/18 (pending), on which the author acts as lead counsel, as a member of GLAN, on behalf of the applicants. For further details, see Violeta Moreno-Lax, 'The Architecture of Functional Jurisdiction: Unpacking Contactless Control - On Public Powers, S.S. and Others v. Italy, and the "Operational Model"' (2020) 21 German Law Journal 385.

157 Violeta Moreno-Lax and Martin Lemberg-Pedersen, 'Border-induced Displacement: The Ethical and Legal Implications of Distance-creation through Externalization' (2019) 56 Questions of International Law $5<$ www.qil-qdi.org/border-ind uced-displacement-the-ethical-and-legal-implications-of-distance-creation-throug h-externalization/>.

158 'New Pact on Migration and Asylum' (n 2), 16.

159 The term is inspired by Matthew J. Gibney, 'A Thousand Little Guantánamos: Western States and Measures to Prevent the Arrival of Refugees' in Kate E. 
embeds rather than overhauls the failed hotspot approach. ${ }^{160}$ Inevitably, the international SAR regime and the customary international legal obligation to render assistance and rescue at sea on which it is based (including disembarkation in a 'place of safety' in line with non-refoulement guarantees ${ }^{161)}$ will be disfigured and betrayed. The supposedly new common European approach to SAR will thus prolong non-rescue practices, embed the criminalisation of solidarity, and sanction defection from international standards and the EU acquis. So, in the final assessment, I need to concur with Commissioner Johansson and conclude that 'no one will be satisfied' with the New Pact proposals—at least, no one should. ${ }^{162}$

Tunstall (ed), Displacement, Asylum, Migration: The Oxford Amnesty Lectures 2004 (Oxford University Press 2006), 139.

160 FRA, 'Update of the 2016 Opinion of the European Union Agency for Fundamental Rights on fundamental rights in the "hotspots" set up in Greece and Italy' (February 2019) <https://fra.europa.eu/sites/default/files/fra_uploads/fra-20 19-opinion-hotspots-update-03-2019_en.pdfs.

161 UNHCR, IMO and ICS, 'Rescue at Sea: A Guide to Principles and Practices as Applied to Refugees and Migrants' (January 2015) <www.unhcr.org/450037d34. pdf $>$. See also ECtHR, Hirsi Jamaa and Others v. Italy (n 110).

162 Eszter Zalan, 'Commissioner: No One will Like New EU Migration Pact' (EU Observer, 18 September 2020) <https://euobserver.com/migration/149475>. 
